\title{
ESTIMATES OF INFECTION AND MORTALITY FROM COVID-19 IN CARE HOMES FOR OLDER PEOPLE IN BRAZIL
}

\author{
Estimativas de infecção e mortalidade por \\ COVID-19 em lares de idosos no Brasil
}

\author{
Patrick Alexander Wachholz ${ }^{\circledR}$, Virgilio Garcia Moreirab $\bullet$, Déborah Oliveira` ${ }^{\oplus}$, \\ Helena Akemi Wada Watanabed ${ }^{\circledR}$, Paulo José Fortes Villas Boas ${ }^{a}$ ๑๑
}

\begin{abstract}
OBJECTIVE: To describe infection and mortality rates associated with COVID-19 in older people living in Brazilian care homes. METHODS: A descriptive cross-sectional study was conducted using primary and secondary data sources. Nationwide care home administrators were invited to report, via an online questionnaire, the occurrence of infection and mortality associated with COVID-19 from April to August 2020. State Public Prosecutor Offices, State Health Departments, and the Unified Social Security System were also contacted for information. Data were analyzed using descriptive statistics. RESULTS: Data were collected from 2154 care homes located in 14 states, covering 59878 older residents. The incidence rate of COVID-19 was $6.57 \%$, and 883 deaths were recorded in the period, with a case-fatality rate of $22.44 \%$. CONCLUSIONS: The incidence and mortality rates observed in this study were lower than those observed in other (high-income) countries. Data sources related to COVID-19 outbreaks in Brazilian care homes are currently limited to self-report. Structuring and systematizing data recording and reporting in these settings is essential to better understand the spread of the virus and to protect care home residents in Brazil. KEYWORDS: aged; coronavirus; homes for the aged.
\end{abstract}

OBJETIVO: Descrever as taxas de infecção e mortalidade associadas a COVID-19 em idosos residentes em lares geriátricos brasileiros. MÉTODOS: Foi realizado um estudo transversal descritivo, utilizando fontes primárias e secundárias de dados. Os administradores de lares geriátricos em todo o país foram convidados a relatar, por meio de um questionário online, a ocorrência de infecção e mortalidade associadas a COVID-19 de abril a agosto de 2020. Os gabinetes dos Procuradores Regionais da República, as Secretarias Estaduais de Saúde e o Sistema Único de Assistência Social também foram contatados para informações. Os dados foram analisados por meio de estatística descritiva. RESULTADOS: Foram coletados os dados de 2154 lares de idosos localizados em 14 estados, cobrindo 59878 idosos residentes. A taxa de incidência de COVID-19 foi de 6,57\%, e foram registrados 883 óbitos no período, com uma taxa de letalidade dos casos de 22,44\%. CONCLUSÕES: As taxas de incidência e mortalidade observadas neste estudo foram inferiores às observadas em outros países (de alta renda). As fontes de dados relacionadas a surtos de COVID-19 em lares geriátricos brasileiros são atualmente limitadas a autorrelato. Estruturar e sistematizar o registro e a notificação de dados nesses locais é essencial para um melhor entendimento da disseminação do vírus e para a proteção dos residentes de lares geriátricos no Brasil.

PALAVRAS-CHAVE: idoso; coronavírus; instituição de longa permanência para idosos.

aBotucatu Medical School, Universidade Estadual Paulista “Júlio de Mesquita Filho” - Botucatu (SP), Brazil. 'Human Aging Research Laboratory, Department of Internal Medicine, School of Medical Sciences, Universidade do Estado do Rio de Janeiro Rio de Janeiro (RJ), Brazil.

'Department of Psychiatry, Paulista School of Medicine, Universidade Federal de São Paulo - São Paulo (SP), Brazil.

dDepartment of Policy, Management and Health, Public School of Health, Universidade de São Paulo - São Paulo (SP), Brazil.

Correspondence data

Autor correspondente: Patrick Wachholz - Faculdade de Medicina, Universidade Estadual Paulista "Júlio de Mesquita Filho" - Avenida Professor Mário Rubens Guimarães Montenegro, s/n - Campus Unesp - CEP: 18618-687 - Botucatu (SP), Brazil. E-mail: patrick.wachholz@unesp.br

Received on: 10/15/2020. Accepted on: 11/22/2020

https://doi.org/10.5327/Z2447-212320202000127 


\section{INTRODUCTION}

In countries such as Canada, Ireland, and France, care home residents accounted for more than $50 \%$ of the COVID-19 mortality rate up to June 2020. ${ }^{1}$ In the United Kingdom, approximately $72 \%$ of all COVID-19-related deaths among care home residents have occurred in these facilities rather than in hospitals. ${ }^{1}$ In the United States, more than 10000 deaths were reported in care homes up to August 2020. ${ }^{2}$ However, similar data related to care homes in Brazil and other low- and middle-income countries are scarce.

The exact number of existing care homes in Brazil is unknown, and so is the profile of older people living in such settings. A national census conducted from 2007 to 2010 identified more than 3500 care homes in Brazil. ${ }^{3}$ However, many facilities were not accounted for because they were not legally registered at the time. Members of the São Paulo State Prosecutor's Office (PO) suggest that the number of older people living in care homes in the region was over 35000 people in 2020 (self-reported and non-official information collected by the researchers in July 2020).

There are several other reasons why collecting reliable and systematic data on the spread and impact of infectious diseases, such as COVID-19, in care home residents and staff members in Brazil is a challenge and can jeopardize the planning and implementation of effective public health policies. First, care homes in Brazil are considered to be social rather than health care providers, and as such, they are not required by law to have health professionals as part of their staff. Second, flagging outbreaks in care homes and reporting them to local health authorities usually depend on the willingness of homeowners and initiative of the PO. Finally, the system used by the federal government to monitor the COVID-19 pandemic in Brazil does not stratify data by place of residence, so the number of infected care home residents and workers is not officially accounted for. As a result, to date, the number of care home residents affected by the COVID-19 pandemic in Brazil is mostly unknown.

This study aimed to describe infection and mortality rates associated with COVID-19 in older people living in care homes in Brazil. This paper updates and complements the preliminary report publicly available online as a preprint. ${ }^{4}$

\section{METHODS}

A cross-sectional study was conducted using primary and secondary data sources. The study was approved by the National Research Ethics Committee (CONEP) (CAAE
No. 30577520.0.0000.0008). Data were collected between April 17 and August 20, 2020.

Using an online questionnaire, we invited 105 Brazilian care home administrators to report infection and mortality rates associated with COVID-19 in their care home residents. Contact details were obtained through publicly available online sources. The POs of all 26 Brazilian states were contacted by email. We also consulted health departments, surveillance agencies, and the Unified Social Security System (SUAS) by email and/or telephone. The online questionnaire included the following variables: number of care homes and total number of older residents in each facility; number of residents with suspected or laboratory-confirmed COVID-19; and number of confirmed deaths from COVID-19. Where data for the same care home had been collected by more than one source (eg, by the $\mathrm{PO}$ and care home administrators in the same region), only the most recent data were included in the analysis. In addition to the online questionnaire, we consulted the epidemiological bulletins of all 26 Brazilian states and the Federal District published on their websites to gather further relevant information. Data were analyzed using descriptive statistics.

\section{RESULTS}

We received anonymized data from 12 of the $26 \mathrm{POs}$ contacted (response rate of $46.15 \%$ ) and from 78 Brazilian care home administrators (response rate of 74.28\%). A total of 2154 care homes located in 14 states (Ceará, Espírito Santo, Goiás, Minas Gerais, Mato Grosso, Paraná, Pernambuco, Piauí, Rio de Janeiro, Rio Grande do Norte, Rio Grande do Sul, Roraima, Santa Catarina, and São Paulo), covering 59878 older residents, returned a completed questionnaire. Official data published online, specifically involving care home residents, were found for only one state (Rio Grande do Sul). Overall, there were 3934 laboratory-confirmed cases of COVID-19 among the 59878 residents, and a total of 883 COVID-19-related deaths (infection rate of $6.57 \%$; case-fatality rate of $22.44 \%$ ). Table 1 shows infection rates and deaths related to COVID-19 in a sample of long-term care homes for older people in Brazil during the study period.

\section{DISCUSSION}

This study is one of the few voluntary academic task forces aimed at gathering information about COVID19 outbreaks in care homes in Brazil. With the exception 
Table 1. Infection rates and deaths related to COVID-19 in a sample of long-term care homes for older people in Brazil (June/2020).

\begin{tabular}{|c|c|c|c|c|c|}
\hline State & $\begin{array}{l}\text { Number of } \\
\text { care homes }\end{array}$ & $\begin{array}{l}\text { Number of } \\
\text { residents }\end{array}$ & $\begin{array}{l}\text { Confirmed } \\
\text { COVID-19 cases }\end{array}$ & $\begin{array}{c}\text { Confirmed } \\
\text { COVID-19 deaths }\end{array}$ & $\begin{array}{l}\text { Data source } \\
\text { and date }\end{array}$ \\
\hline Ceará & 60 & 1691 & 129 & 64 & Ceará PO, 07/Aug/2020 \\
\hline Espírito Santo & 94 & 1601 & 455 & 71 & Espírito Santo PO, 14/Aug/2020 \\
\hline Goiás & 3 & 153 & 0 & 0 & Care home administrators, July 2020 \\
\hline Minas Gerais & 94 & 1900 & NA & 22 & $\begin{array}{l}\text { Personal communication } \\
\text { Karla Giacomin, 18/Aug/2020 }\end{array}$ \\
\hline Mato Grosso & 5 & 188 & 9 & 02 & Mato Grosso PO, 28/Jul/2020 \\
\hline Paraná & 105 & 2257 & 149 & 20 & Paraná PO, 08/Aug/2020 \\
\hline Pernambuco & 26 & 732 & 108 & 60 & Pernambuco PO, 17/Jul/2020 \\
\hline Piauí & 9 & 358 & 26 & 5 & Piauí PO, 29/Jul/2020 \\
\hline Rio de Janeiro & 6 & 191 & 83 & 17 & Care home administrators, July 2020 \\
\hline Rio Grande do Norte & 47 & 1141 & 78 & 14 & Rio Grande do Norte PO, 13/Jul/2020 \\
\hline Rio Grande do Sul & NA & 2807 & 678 & 84 & $\begin{array}{l}\text { Rio Grande do Sul Health } \\
\text { Department, 12/Aug/2020 }\end{array}$ \\
\hline Roraima & 1 & 30 & 0 & 0 & Roraima PO, 14/Jul/2020 \\
\hline Santa Catarina & 242 & 6074 & 132 & 18 & Santa Catarina PO, 20/Jul/2020 \\
\hline São Paulo & 1462 & 40755 & 2087 & 506 & São Paulo PO, 22/Jul/2020 \\
\hline Total & 2154 & 59878 & 3934 & 883 & \\
\hline
\end{tabular}

NA: not available; PO: prosecutor's office.

of one state, infection and mortality rates associated with COVID-19 among older people living in Brazilian care homes have not been officially stratified or reported in government epidemiological bulletins. Our data were therefore collected mostly from self-reported and non-official sources, resulting in an infection rate of $6.57 \%$ and a case-fatality rate of $22.44 \%$.

The odds of transmitting the virus appear to be higher in care home populations than in the general population., This might be explained both by the high level of need for assistance in daily activities resulting from functional and cognitive impairment among most older adults living in such settings, and by the high prevalence of comorbidities, frailty, and immunosenescence. ${ }^{7}$ Despite the high vulnerability to infection detected in older care home residents in other countries, only one study has been conducted so far to estimate the impact of the COVID-19 pandemic in Brazilian care homes. ${ }^{8}$ Based on other countries' estimates, the authors found an infection rate of $44.7 \%$ and a total of 107538 deaths, which are much higher rates than the ones found in the present study. We believe that such differences are due to the many existing limitations in data gathering in such settings nationwide. Also, the information received early on about the virus outbreak in European countries and the United States might have helped alert our authorities and homeowners to the need to restrict visits and social activities, ${ }^{9,10}$ which might have contributed to the much lower case and mortality rates we detected in care homes in Brazil. This association, however, remains unclear and to be confirmed.

Despite having received information from a large number of care homes, our study has several limitations. The cross-sectional design used to analyze an ongoing pandemic does not necessarily provide an accurate picture of the longterm impact of the virus outbreak in Brazilian care homes. In addition, we have a high concentration of data coming predominantly from two states, with low representation of the North and Northeast regions. Other confounding variables, such as bias introduced by collecting data from secondary sources, need to be considered when interpreting our results. Future research should concentrate efforts to seek official sources of epidemiological data, to assess the impact and morbidity and mortality profiles of the pandemic on the health and wellbeing of care home residents, and to monitor changes in infection and mortality rates as care homes begin to reopen for visitors. 


\section{CONCLUSION}

The estimated rates of COVID-19 observed in this study were lower than those observed in other (high-income) countries, with an incidence rate of $6.57 \%$ and a case-fatality rate of $22.44 \%$. Structuring and systematizing data recording and reporting in these settings is essential to better understand the spread of the virus and to protect care home residents in Brazil.

\section{CONFLICTS OF INTEREST}

The authors declare no conflicts of interest.

\section{FUNDING}

None.

\section{AUTHORS' CONTRIBUTION}

PAW: conception or design of the work, data collection, data analysis and interpretation, drafting the article, critical revision of the article, final approval of the version to be published. VGM: data collection, data analysis and interpretation, drafting the article, critical revision of the article, final approval of the version to be published. DO: conception or design of the work, data analysis and interpretation, drafting the article, critical revision of the article, final approval of the version to be published. HAWW: data collection, data analysis and interpretation, drafting the article, critical revision of the article, final approval of the version to be published. PJFVB: data collection, data analysis and interpretation, drafting the article, critical revision of the article, final approval of the version to be published.

\section{REFERENCES}

1. Comas-Herrera A, Zalakain J. Mortality Associated with COVID-19 Outbreaks in Care Homes: Early International Evidence. 2020. Accessed on Oct 2, 2020. Available in: https://tccovid.org/wp-content/ uploads/2020/10/Mortality-associated-with-COVID-among-peopleliving-in-care-homes-14-October-2020-3.pdf

2. Coe NB, Van Houtven CH. Living Arrangements of Older Adults and COVID-19 Risk: It Is Not Just Nursing Homes. J Am Geriatr Soc. 2020;68(7):1398-9. https://doi.org/10.1111/jgs.16529

3. Camarano AA, Kanso S. As instituições de longa permanência para idosos no Brasil. Rev Bras Estud Popul. 2010;27(1):232-5. https:// doi.org/10.1590/S0102-30982010000100014

4. Wachholz PA, Moreira VG, Oliveira D, Watanabe HAW, Villas Boas PJF. Occurrence of infection and mortality by COVID-19 in care homes for older people in Brazil [electronic journal] 2020 [accessed on Sep. 30, 2020]. Available in: https://preprints.scielo. org/index.php/scielo/preprint/view/1032 https://doi.org/10.1590/ SciELOPreprints.1032

5. Wachholz PA, Ferri CP, Mateus E, Mata F, Oliveira D. The COVID-19 situation in Brazilian care homes and actions taken to mitigate infection and reduce mortality [electronic journal] 2020 [accessed on Sep. 30, 2020]. Available in: https://tccovid.org/wp-content/ uploads/2020/06/Brief-summary-of-the-COVID-19-situation-carehomes-Brazil_FINAL.pdf
6. D’Adamo H, Yoshikawa T, Ouslander JG. Coronavirus Disease 2019 in Geriatrics and Long-term Care: The ABCDs of COVID-19: COVID-19 in Geriatrics and Long-Term Care. J Am Geriatr Soc. 2020;68(5):912-7. https://doi.org/10.1111/jgs.16445

7. British Geriatric Society. Managing the COVID-19 Pandemic in Care Homes. BGS [Internet] 2020 [accessed on Sep. 15, 2020]. Available in: www.bgs.org.uk/COVID-19

8. Machado CJ, Pereira CC de A, Viana B de M, Oliveira GL, Melo DC, Carvalho JFMG, et al. Estimates of the impact of COVID-19 on mortality of institutionalized elderly in Brazil. Ciên Saúde Colet. 2020;25(9):3437-44 http://doi.org/10.1590/1413-81232020259.14552020

9. Special Commission COVID-19, Brazilian Society of Geriatrics and Gerontology. Recommendations for the prevention and control of coronavirus infections (SARS-CoV-2) in long term care facilities. Geriatr Gerontol Aging. 2020;14(2):134-7. http://doi.org/10.5327/ Z2447-2123202020142ESP3

10. Brasil. GVIMS-GGTES-ANVISA. Nota Técnica n 05-2020 GVIMS-GGTESANVISA - Orientações para a prevenção e o controle de infecções pelo novo coronavírus em instituições de longa permanência para idosos (ILPI). Brazil: Anvisa; 2020. Accessed on Aug 31,2020. Available in: https:// uww20.anvisa.gov.br/segurancadopaciente/index.php/alertas/item/notatecnica-n-05-2020-gvims-ggtes-anvisa-orientacoes-para-a-prevencaoe-o-controle-de-infeccoes-pelo-novo-coronavirus-sars-cov-2-ilpi 